\title{
Single Plaque-Type Chromoblastomycosis: Great and Sustained Response with Itraconazole Plus Cryosurgery
} \author{
Moreira Amorim ${ }^{1,2 *}$ \\ ${ }^{1}$ Faculty of Medicina of South Santa Catarina Universisty, Brazil \\ ${ }^{2}$ Santa Tereza Sanitary Dermatology Hospital / Santa Catarina Health Secretary, Brazil \\ ${ }^{3}$ Anatomical Pathology Institute / Santa Catarina Health Secretary, Brazil
}

Mariana Costa Garcia ${ }^{1}$, Bruna Moretto ${ }^{1}$, Marta Vainchenker ${ }^{3}$, Roberto Moreira Amorim Filho ${ }^{2}$ and Gustavo

Submission: February 04, 2020; Published: February 14, 2020

*Corresponding author: Gustavo Moreira Amorim. Dermatologist from Federal University of Rio de Janeiro. Master's Degree in Anatomical Pathology from Federal University of Rio de Janeiro. Dermatology Professor from Faculty of Medicina of South Santa Catarina Universisty. Dermatology from Santa Tereza Sanitary Dermatology Hospital da Faculdade de Medicina da Universidade do Sul de Santa Catarina. Médico Dermatologista, Brazil

Abstract

We present a 72-years-old male patient, resident in a urban area, with a chronic cutaneous ulcer on the left forearm, diagnosed with chromoblastomycosis, treated with a combination therapy of oral itraconazole and cryocirurgery, with 6-months follow up after treatment.

Keywords: Black Fungi; Chromoblastomycosis; Chromomycosis; Melanized Fungi; Muriform (Sclerotic) Cells

\section{Introduction}

The Chromoblastomycosis (CBM) is a chronic fungal infection caused by the traumatic implantation of demeaceous fungi of the Herpotrichiellaceae family on the skin and subcutaneous cellular tissue [1-3]. These fungi are more common in tropical and subtropical areas, and can be found in the soil, in vegetation and decomposing wood [1,2]. It is more common in male rural workers, lumbermen or sellers of agricultural products [4]. Brazil is the second country in number of cases, being found throughout its entire territory $[2,5]$.

\section{History and Clinical Manifestations}

Malepacient, 72years, urban dweller, retired(former bricklayer), sought medical attention due to injury to the left forearm. It started 6 months earlier as a papulo-pustular lesion, wich progressed slowly and progressively to an erythematous plaque, with a rough surface; asymptomatic. Upon examination, an infiltrated, erythetous-keratotic plaque was indentified, with well-defined edges and an irregular, slightly verrucous surface, measuring about $5.0 \mathrm{~cm}$ in the largest diameter (Figure 1). Dermoscopy indentified black dots (Figure 2). When questioned, he associated the injury with a sharp puncture trauma during the repair of the house fence. With the hypothesis of subcutaneous mycosis (chromomycosis and sporotrichosis), tuberculosis, in addition to neoplasia (squamous cell carcinoma), an incisional biopsy was performed.

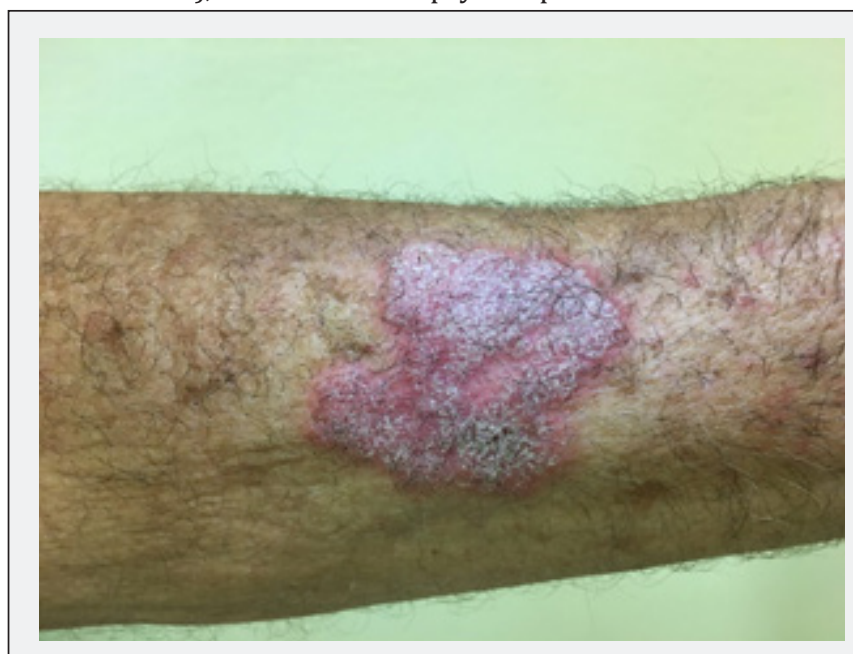

Figure 1: Erythetous-keratotic plaque. 


\section{Juniper Online Journal of Dermatology \& Cosmetics}

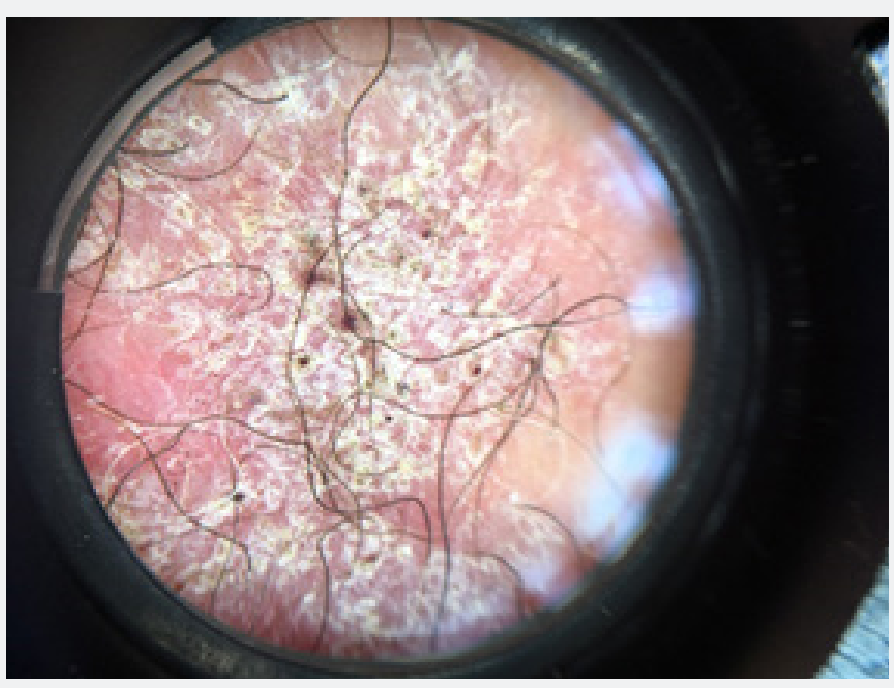

Figure 2: Dermoscopy indentified black dots.

Histopathological examination showed chronic granulomatous dermatitis associated with pseudoepitheliomatous hyperplasia of the epidermis. In the dermis, the presence of sclerotic cells (Figure 3), confirming the diagnosis of Chromoblastomycosis. Fungal culture isolated the demeaceous fungus Fonsecaea Pedrosoi.
Treatment with Itraconazole $200 \mathrm{mg}$ /day for 6 months, associated with 4 sessions of Cryosurgery (local infiltrative anesthesia, tip B, intermittent jets, 2 cycles, thawing time 2 times that of freezing) at 1-month intervals. Apparent clinical cure 6 months after the end of treatment (Figure 4).

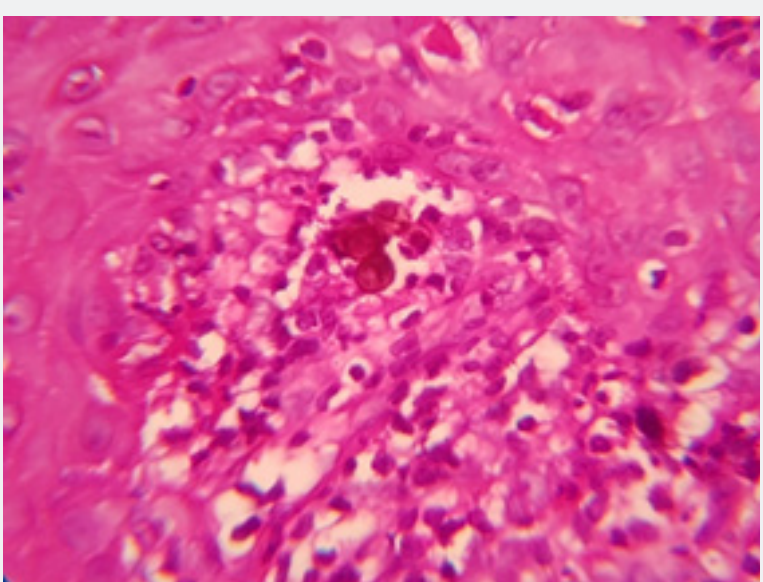

Figure 3: diagnosis of Chromoblastomycosis.

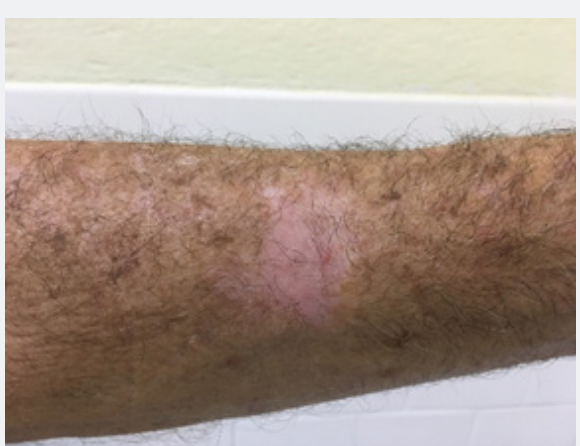

Figure 4: Apparent clinical cure 6 months after the end of treatment. 


\section{Discussion}

CBM begins with a primary lesion at the traumatic fungus inoculation site, usually oligosymptomatic, delaying the demand for care $[2,4]$. A papule is noted, usually in areas of exposed skin, wich grows in a centrifugal manner. There may be progression of the condition due to contiguity, in addition to lymphatic and/ or hematogenic dissemination $[1,2,6]$. It is classified clinically in 5 types: nodular, verrucous or verruciform, plaque, tumor and scar or atrophic. Possible complications are secondary bacterial infection, elephantiasis and carcinomatous degeneration $[2,6]$. The differential diagnosis is made with paracoccidioidomycosis, sporotrichosis, lacaziosis, leishmaniasis, mycetomas, leprosy, tuberculosis, atypical mycobacteriosis, prototecosis, in addition to squamous cell carcinoma [2].

Epidemiology assists in diagnosis, especially in endemic areas.4 This can be confirmed by visualization of the fungus in direct examination, in tissues with histopathological examination, in addition to culture isolation.5 The sclerotic (muriform) cells are pathognomonic for CBM, regardless of the causative species [2]. The treatment is difficult, with recurrence and chronic lesions being common.6 There is no gold standard of treatment. Some options are cryosurgery, carbon, dioxide laser, itraconazole, flucytosine, terbinafine, amphotericin B, fluconazole, posaconazole, imiquimod, super-satured potassium iodide and thermotherapy, used alone or in combination. The choice depends on the age and comorbidities of the pacient, as well as the location of the lesions [5]. Cryosurgery with liquid nitrogen and thermotherapy are suitable options for isolated and limites lesions [2]. Already the antifungals that have shown greater effectiveness are itraconazole and terbinafine for 6 to 12 months, preferably in higher doses, if tolerated [2].

\section{Conclusion}

We present an illustrative case of CBM, plaque shape, in an elderly man from an urban area, with a report after questioning trauma involving a wooden and wire fence, seeking to draw attention to this entity in the day-to-day of the dermatologist even if outside endemic area and without typical epidemiology. In parallel, a good therapeutic result is demonstrated with the association of surgical and medication techniques, which are accessible and well tolerated.

\section{References}

1. Purin KSM, Pereti MC, Fillus-Neto J, Olandoski M (2017) Chromoblastomycosis: Tissue modifications during itraconazole treatment. An Bras Dermatol 92(4): 478-483.

2. Brito AC De, Jesus M De, Bittencourt S (2018) Chromoblastomycosis: etiological, epidemiological, clinical, diagnostic and therapeutic update. An Bras Dermatol 93(4): 495-506.

3. Sali AP, Sahay A (2017) Chromoblastomycosis of the leg. Pol J Pathol 68(2): 182-184.

4. Queiroz Telles F (2015) Chromoblastomycosis: A neglected tropical disease. Rev Inst Med Trop Sao Paulo 57(1): 46-50.

5. Queiróz AJR, Pereira Domingos F, Antônio JR (2018) Chromoblastomycosis: clinical experience and review of literature. Int J Dermatol 57(11): 1351-1355.

6. Queiroz Telles F, De Hoog S, Santos DW, Salgado CG, Vicente VA, et al (2017) Chromoblastomycosis. Clinical Microbiol Rev 30(1): 233-276.

\section{Your next submission with Juniper Publishers will reach you the below assets}

- Quality Editorial service

- Swift Peer Review

- Reprints availability

- E-prints Service

- Manuscript Podcast for convenient understanding

- Global attainment for your research

- Manuscript accessibility in different formats

( Pdf, E-pub, Full Text, Audio)

- Unceasing customer service

\section{Track the below URL for one-step submission}

https://juniperpublishers.com/online-submission.php 